\title{
The C2 Protein from the Geminivirus Tomato Yellow Leaf Curl Sardinia Virus Decreases Sensitivity to Jasmonates and Suppresses Jasmonate-Mediated Defences
}

\author{
Tábata Rosas-Díaz ${ }^{1,2}$, Alberto P. Macho ${ }^{1,2}$, Carmen R. Beuzón ${ }^{1}$, Rosa Lozano-Durán ${ }^{1,2, *,+}$ and \\ Eduardo R. Bejarano ${ }^{1, *, \dagger}$ \\ Received: 30 October 2015; Accepted: 11 January 2016; Published: 15 January 2016 \\ Academic Editor: Debora Gasperini \\ 1 Departamento de Biología Celular, Genética y Fisiología, Instituto de Hortofruticultura \\ Subtropical y Mediterránea, Universidad de Málaga-Consejo Superior de Investigaciones Científicas, \\ Campus de Teatinos, E-29071 Malaga, Spain; tabatarosas@sibs.ac.cn (T.R.-D.); \\ alberto.macho@sibs.ac.cn (A.P.M.); cbl@uma.es (C.R.B.) \\ 2 Shanghai Center for Plant Stress Biology (PSC), Shanghai Institutes of Biological Sciences, \\ Chinese Academy of Sciences, Shanghai 201602, China \\ * Correspondence: lozano-duran@sibs.ac.cn (R.L.-D.); edu_rodri@uma.es (E.R.B.); \\ Tel.: +86-021-57078280 (R.L.-D.); +34-952131677 (E.R.B.) \\ + These authors contributed equally to this work.
}

\begin{abstract}
An increasing body of evidence points at a role of the plant hormones jasmonates (JAs) in determining the outcome of plant-virus interactions. Geminiviruses, small DNA viruses infecting a wide range of plant species worldwide, encode a multifunctional protein, $\mathrm{C} 2$, which is essential for full pathogenicity. The $\mathrm{C} 2$ protein has been shown to suppress the JA response, although the current view on the extent of this effect and the underlying molecular mechanisms is incomplete. In this work, we use a combination of exogenous hormone treatments, microarray analysis, and pathogen infections to analyze, in detail, the suppression of the JA response exerted by $\mathrm{C} 2$. Our results indicate that C2 specifically affects certain JA-induced responses, namely defence and secondary metabolism, and show that plants expressing $\mathrm{C} 2$ are more susceptible to pathogen attack. We propose a model in which C2 might interfere with the JA response at several levels.
\end{abstract}

Keywords: plant virus; jasmonates; defence; $\mathrm{C} 2$; $\mathrm{SCF}^{\mathrm{CO} 1}$; coronatine; geminivirus

\section{Introduction}

Geminiviruses are a large family of plant viruses with circular, single-stranded (ss) DNA genomes packaged within geminate particles [1], which infect a broad range of staple and fiber crops worldwide and cause devastating diseases that lead to serious economic losses. Geminiviral genomes are small, ranging from 2.5 to $5.5 \mathrm{~Kb}$, which imposes limitations in coding capacity. These viruses, however, seem to have compensated these restrictions by evolving overlapping and bidirectional open reading frames (ORFs), encoding four to eight multifunctional proteins that effectively manipulate plant functions to favor infection.

The multifunctionality of geminiviral proteins can be exemplified by C2 from monopartite geminiviruses belonging to the genus Begomovirus. Begomoviral C2 is a small protein, around $15 \mathrm{KDa}$ in size, which localizes mainly in the nucleus of the plant cell. This protein has been shown to be required for either viral infection or full infectivity in several cases, suggesting a high-value role during geminivirus infection [2-6]. C2 has been described as a transcription factor for viral 
genes $[7,8]$ and a suppressor of gene silencing, both post-transcriptional (PTGS) and transcriptional (TGS) [2,9-15]. Additionally, C2 from two different begomoviruses, Tomato yellow leaf curl Sardinia virus (TYLCSV) and Tomato yellow leaf curl virus (TYLCV), interacts with the catalytic subunit of the CSN (COP9 signalosome) complex, affecting the ability of the CSN to regulate ubiquitin E3 ligase complexes belonging to the SCF (SKP1, CUL1/CDC53, F-box proteins) family [4]. Consequently, C2 impairs cellular processes regulated by SCF complexes when transgenically expressed in Arabidopsis; remarkably, the response to jasmonates specifically appears significantly repressed by $\mathrm{C} 2$ in microarray analyses [4].

The oxylipin jasmonic acid (JA) and its metabolites, collectively known as jasmonates (JAs), are important plant signalling molecules that mediate biotic and abiotic stress responses, as well as several aspects of plant growth and development [16]. In basal conditions, JA levels are low and JA-mediated transcriptional responses are kept in a repressed state by JASMONATE ZIM-DOMAIN (JAZ) proteins. In response to stresses, such as insect feeding or necrotrophic pathogen infection, an increase in the levels of the bioactive jasmonate JA-Ile allows this hormone to act as molecular glue, facilitating the interaction between the JAZ repressors and the F-box protein CORONATINE INSENSITIVE 1 (COI1), recognition component of the JA receptor, the E3 ubiquitin ligase SCFCOI1. The result of this interaction is the targeting of JAZs for ubiquitination and degradation via the $26 \mathrm{~S}$ proteasome pathway, allowing for the expression of JA-responsive genes $[17,18]$. JA-dependent transcriptional reprogramming is regulated by a cascade of transcription factors (TFs), in which MYC2 plays a major role, as indicated by the lower sensitivity to JA displayed by the jin1 mutant, carrying a mutation in the MYC2 gene $[19,20]$. JAZ proteins directly interact with MYC2 in the absence of JA, keeping this transcription factor inactive [17]; degradation of JAZ proteins in response to JAs allows MYC2 to exert its effect on downstream target genes. JAZ proteins have also been shown to interact with MYC3 and MYC4, among other TFs [16,21-23]. Notably, JAZ expression is induced after JA perception or wounding, indicating that JAZ repressors are also JA-responsive genes, as part of a negative feedback loop regulation of JA responses [24].

Although traditionally jasmonate-mediated defences have been ascribed a role against necrotrophic pathogens and herbivorous insects, a growing body of evidence now points at these hormones as acting also in plant-virus interactions [17,25-32] Moreover, interference with JA-regulated gene expression seems to be a general property of viral suppressors or RNA silencing, since it has been observed in transgenic plants expressing p25, HC-Pro, $126 \mathrm{KDa}$ and $2 \mathrm{~b}$ [33], as well as geminiviral C2 [4], V2 (Luna, Lozano-Durán and Bejarano, unpublished), and $\beta C 1$ [31,34].

Recent findings indicate that jasmonate signalling is also altered by geminiviruses. Repression of the jasmonate pathway or jasmonate-responsive genes have been reported in transgenic plants expressing a pathogenicity factor encoded by the DNA $\beta$ of Tomato yellow leaf curl China virus (TYLCCNV) $\beta C 1, C 2$ from TYLCV or TYLCSV, and in Arabidopsis plants infected with Cabbage leaf curl virus (CaLCuV) [4,31,34,35]. Furthermore, exogenous application of methyl jasmonate (MeJA) interferes with Beet curly top virus (BCTV) infection in Arabidopsis, leading to milder symptoms and lower viral accumulation [4]. Remarkably, expression of jasmonic acid biosynthetic genes has been associated to the recovery process in geminivirus-infected pepper [36].

The transcriptional inhibition of the jasmonate signalling pathway and the decreased JA responses in plants expressing C2 from TYLCV or TYLCSV [4] may be linked to an impairment of the function of the jasmonate receptor, the $\mathrm{SCF} C \mathrm{CO} 1$ complex, given the effect of these proteins on the $\mathrm{CSN}$ complex and the SCF ubiquitin E3 ligases, in general. However, both the exact molecular mechanisms underlying this effect and its extent remain to be determined. In this work, we analyze, in detail, the suppression of the JA response exerted by C2 using transcriptomic analyses, as well as the effect of C2 on plant defence through pathogen challenge of C2 transgenic plants. Strikingly, C2-expressing plants show a suppression of JA-mediated defence processes as well as JA-dependent secondary metabolism, which may involve additional, specific protein-protein interactions. 


\section{Results}

\subsection{Transgenic Arabidopsis Plants Expressing C2 from TYLCV or TYLCSV Are Less Sensitive to Bacterial Coronatine}

As a first step to further understand the effect of $\mathrm{C} 2$ on the plant response to JAs, we carried out a root growth inhibition assay in increasing concentrations of methyl-jasmonate (MeJA). As shown in Figure A1, consistent with our previous observations, the MeJA-induced inhibition of root growth is significantly less pronounced in Arabidopsis lines expressing C2 than in control plants for all hormone concentrations tested.

Given that C2 has been shown to affect the function of several SCF complexes in the plant [4], it would be feasible to speculate that the lower sensitivity to jasmonates displayed by the transgenic C2 plants could be due to a malfunction of the SCFCOI1 complex. This SCF complex acts as the jasmonate receptor, but is also the receptor for the bacterial toxin coronatine, an analogue of the bioactive jasmonate JA-Ile which is synthesized and secreted by the plant pathogenic bacterial strain Pseudomonas syringae pv. tomato DC3000 (Pto DC3000) [37-39]. Consequently, if the activity of the $\mathrm{SCF}^{\mathrm{CO} 1}$ is hindered in the presence of the viral protein, transgenic $\mathrm{C} 2$ plants should also be less sensitive to coronatine. In order to test this, transgenic C2 plants were dip-inoculated with Pseudomonas syringae pv. tomato (Pto) DC3000 wild-type or a mutant unable to synthesize coronatine (COR-) and bacterial growth was measured four days post-inoculation (dpi). In the dipping inoculation method, bacteria are forced to enter the plant tissues through natural openings, such as stomata. However, following perception of pathogen-associated molecular patterns (PAMPs), stomatal closure is triggered to prevent pathogen entry; this closure, nevertheless, can be reverted by the successful pathogen Pto DC3000 through the activity of coronatine inside the plant cell [38]. Therefore, wild-type bacteria will trigger the re-opening of the stomata after toxin production and its perception by the plant SCFCOI1 complex, allowing bacterial entry, whereas coronatine-defective bacteria will not, and will thus invade the plant tissues less efficiently [38]. Consistently with this model, our results show that growth of the COR- mutant when dip-inoculated into wild-type Arabidopsis plants is reduced compared to growth of wild-type bacteria (Figure 1A). However, this reduction is lower in the plants expressing C2 from TYLCSV and absent in plants expressing C2 from TYLCV, since bacterial numbers are similar for both strains regardless of whether they can produce coronatine, and similar to those obtained for the COR- mutant in wild-type plants (Figure 1A). A good correlation can be found between symptom severity and bacterial numbers (Figure 1B). These results indicate that the coronatine toxin produced by wild-type bacteria is not properly exerting its function in the C2 transgenic plants. Although we cannot formally rule out that additional targets of C2 impact susceptibility to P. syringae, the small difference between wild-type and coronatine-deficient bacteria in C2 plants can be more likely explained by a combination of two observations: (i) the activity of the SCF complexes is not completely impaired in the C2 plants, but rather partially hindered, so the toxin produced by wild-type bacteria is expected to exert some activity; and (ii) in the absence of coronatine, bacteria will only be able to enter the plant tissues through open stomata whose PAMP-triggered closure has not been accomplished yet. In the $\mathrm{C} 2$ plants, stomata are more efficiently closed as a consequence of ABA hypersensitivity of the guard cells [4], so bacterial entry will be further hampered. Our results are consistent with a reduced sensitivity to coronatine displayed by the $\mathrm{C} 2$ plants and, together with the lower sensitivity to exogenously applied MeJA, support a malfunction of the SCFCOI1 complex. 
A

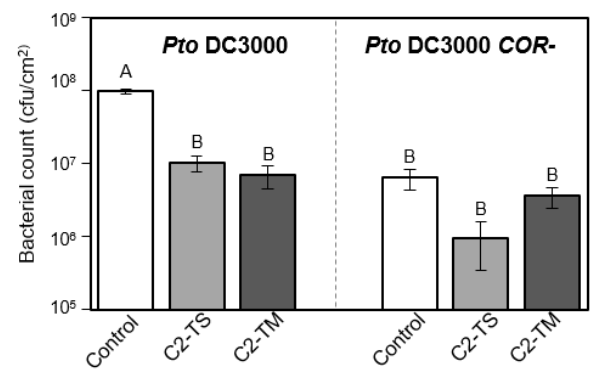

B

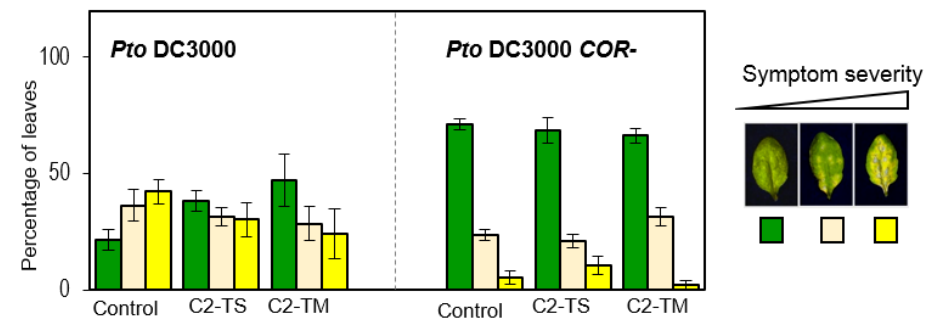

Figure 1. Infection of C2-expressing plants with Pseudomonas syringae pv. tomato DC3000. (A) Bacterial growth of wild-type (Pto DC3000) or a deficient strain unable to synthesize coronatine (COR-) in wild-type Col-0 (control) or transgenic C2-expressing plants in dip-inoculation experiments. Samples were taken at $4 \mathrm{dpi}$. Values are the mean of five plants. Bars represent standard error. One-way ANOVA Tukey's Multiple comparison tests were used to distinguish differences among samples at $p$-value $<0.05$. Different letters indicate statistically significant difference. Results are the mean of three independent biological replicates; (B) Symptoms displayed by dip-inoculated plants. Three different categories are considered: no symptoms, few symptoms or full symptoms, as indicated in the legend. The percentage of leaves in each category is represented. Bars represent standard error. In both (A) and (B), experiments were repeated three times with similar results; results from one representative experiment are shown.

\subsection{C2 Represses Transcriptional JA Responses and JA-Induced Defences}

With the aim of gaining insight into the effect of $\mathrm{C} 2$ on the response to jasmonates, we did a microarray analysis of Arabidopsis transgenic plants expressing C2 from TYLCSV (C2-TS plants) in both basal conditions and after MeJA treatment. For the analysis of transcriptomic data, four comparisons were carried out: (i) C2-TS versus control plants (mock-treated); (ii) MeJA-treated control plants versus mock-treated control plants; (iii) MeJA-treated C2-TS plants versus mock-treated C2-TS plants; and (iv) MeJA-treated C2-TS plants versus MeJA-treated control plants. Differential expression of selected genes was validated by quantitative real-time PCR (Figure A2). The number of up- and down-regulated genes in each comparison is represented in Figure 2. The expression of $\mathrm{C} 2$ in basal conditions causes transcriptional changes, especially involving down-regulation of gene expression, similar to previous results using a CATMA microarray [4]. MeJA treatment triggers dramatic transcriptional changes in Arabidopsis, similar to those shown in previous works [40,41]. Transcriptional changes observed in MeJA-treated C2-TS transgenic plants reveal a reduced response to the hormone: the number of either up- or down-regulated genes after MeJA treatment is lower in the C2-TS plants, and comparison between MeJA-treated C2-TS and control plants reveals a subset of genes differentially expressed in response to MeJA in the presence of $\mathrm{C} 2$, most of them being down-regulated, which indicates the existence of a group of jasmonate-responsive genes that do not respond or respond to a lower extent in the C2-TS plants (Figure 2). 
A

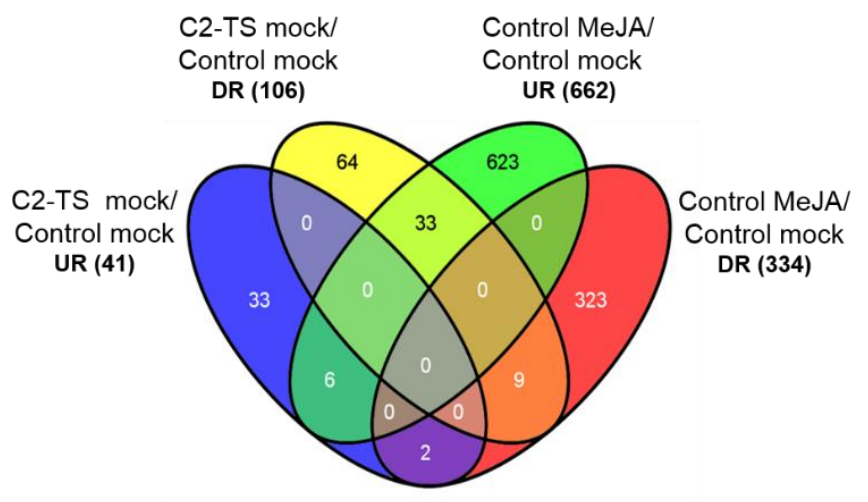

B

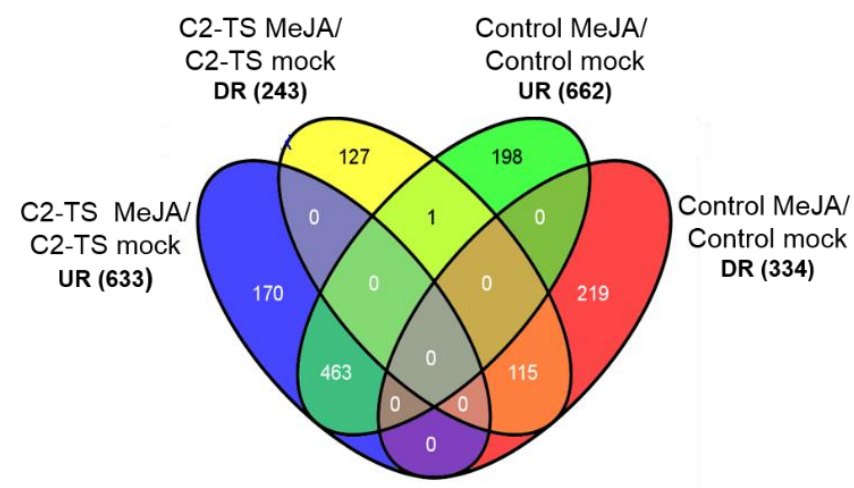

Figure 2. Venn diagrams showing the number of genes up- or down-regulated (UR or DR, respectively) in C2-TS plants, either JA- or mock-treated (in (A,B), respectively), and JA-treated control plants. The Venn diagrams were constructed using the software Venny (http://bioinfogp.cnb.csic.es/tools/venny). Total number of genes in each subset is indicated in brackets.

In order to explore which functional categories are affected by expression of C2 and/or MeJA treatment, a GO functional enrichment analysis was performed using the VirtualPlant BioMaps tool ([42]; http://virtualplant.bio.nyu.edu/cgi-bin/vpweb/). Tables 1-3 show the non-redundant GO terms over-represented in the following subsets of genes: JA-responsive genes repressed by $\mathrm{C} 2$ in basal conditions (Table 1; 33 genes); genes which are JA-responsive in control plants only (Table 2; 198 up-regulated and 219 down-regulated genes); and genes differentially expressed in C2 plants in response to JA, as compared to control plants (Table 3). Our results indicate that the response to JA in plants expressing $\mathrm{C} 2$ is both qualitatively and quantitatively different to that in wild-type plants, and that the main JA-regulated responses affected by $\mathrm{C} 2$ are defence responses and secondary metabolism. A MapMan representation of the effect of C2 on JA-induced defence responses is depicted in Figure 3.

Table 1. Over-represented GO categories (biological function ontology) in the subset of JA-responsive genes repressed by $\mathrm{C} 2$ in basal conditions.

\begin{tabular}{c}
\hline JA-Responsive Genes Repressed by C2 \\
Response to JA \\
Response to biotic stimulus \\
Response to wounding \\
Lipid transport \\
\hline
\end{tabular}


Table 2. Over-represented GO categories (biological function ontology) in the subset of JA-responsive genes in control plants only.

\begin{tabular}{l}
\hline \multicolumn{1}{c}{ JA-Responsive Genes in Control Plants Only } \\
\hline Up-regulated genes \\
\hline Response to stress \\
Response to JA \\
Response to wounding \\
Defence response \\
Biotic stimulus \\
Secondary metabolism \\
\hline Down-regulated genes \\
\hline Growth \\
Cell wall organization \\
Response to auxin and gibberellin \\
Lipid metabolism and transport \\
\hline
\end{tabular}

Table 3. Over-represented GO categories (biological function ontology) in the subset of differentially-expressed genes in C2-expressing plants in response to JA, as compared to control plants.

\begin{tabular}{l}
\hline Differentially Expressed Genes in C2 Plants in Response to JA (Compared to Control Plants) \\
\hline Up-regulated genes \\
\hline Response to stress \\
Response to oxidative stress \\
\hline Down-regulated genes \\
\hline Defence response \\
Multi-organism process \\
Immune system \\
Secondary metabolism \\
Lipid transport \\
\hline
\end{tabular}

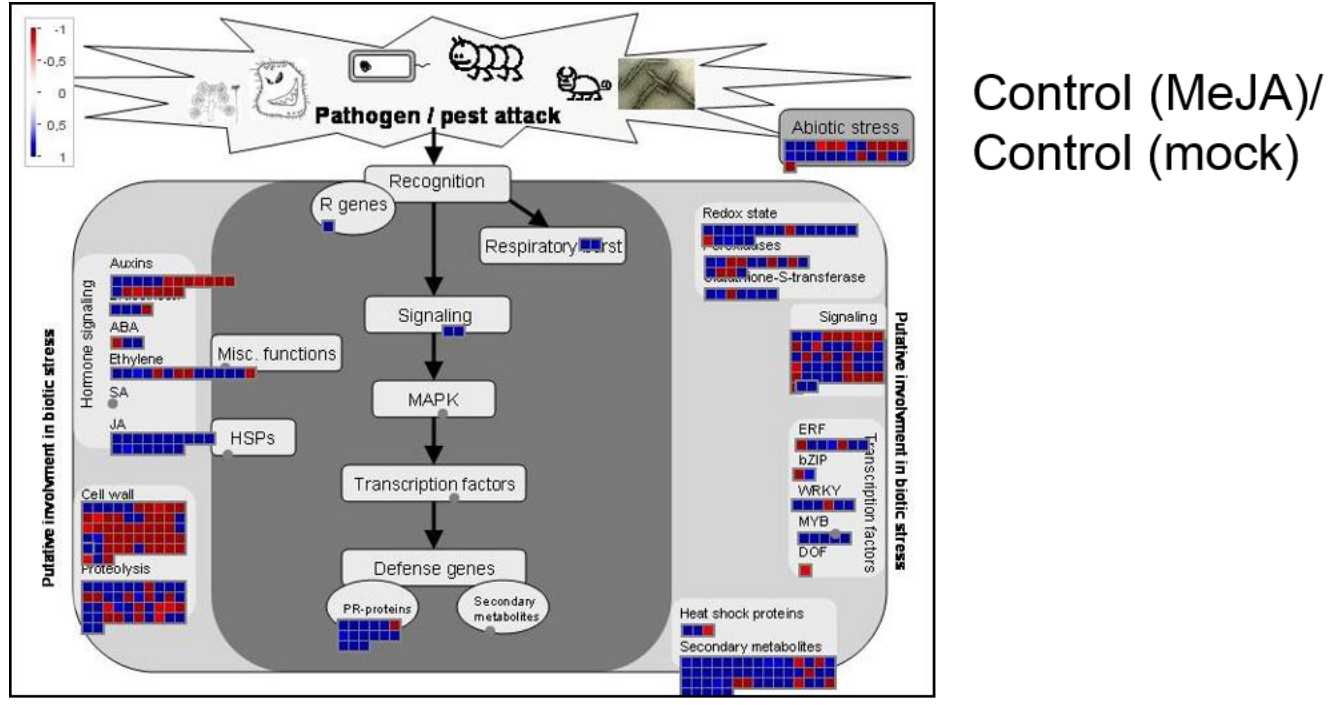

Figure 3. Cont. 


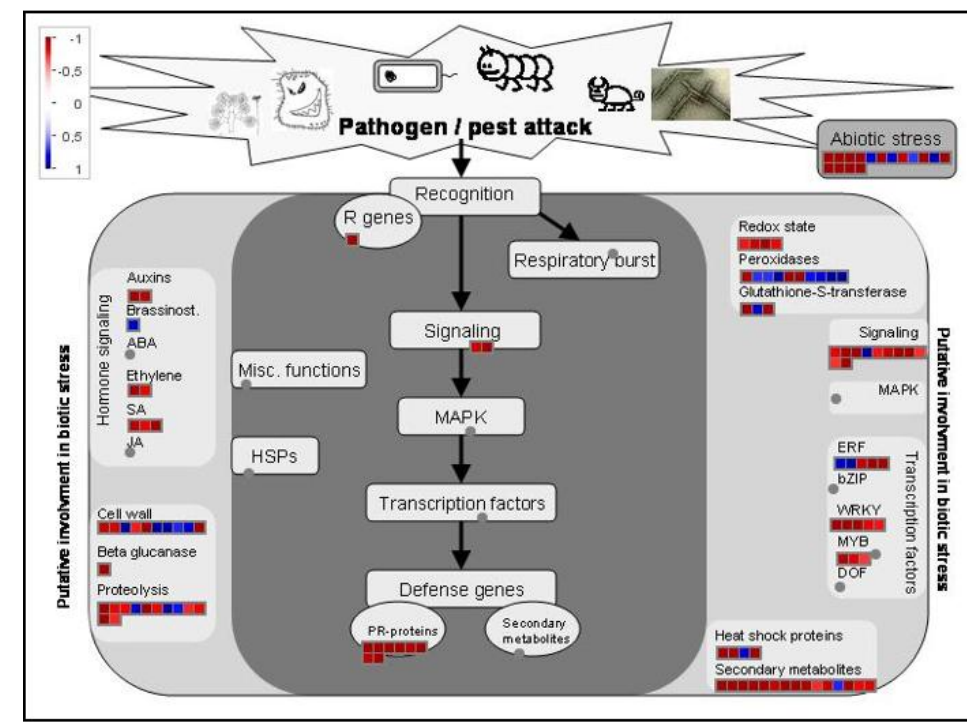

C2-TS (MeJA)/
Control (MeJA)

\section{$\square$ Up-regulated $\quad \square$ Down-regulated}

Figure 3. MapMan visualization of defence-related differentially expressed genes in response to MeJA in control or C2-TS-expressing plants.

\subsection{Transgenic Plants Expressing C2 Are More Susceptible to an RNA Virus and a Plant-Pathogenic} Bacterial Strain

Based on the finding that defence responses are repressed in C2-TS plants (Figure 3; Tables 2 and 3), we decided to test the susceptibility of C2-expressing transgenic lines to different pathogens. For this purpose, we infected transgenic plants expressing C2 with P. syringae or RNA viruses. Arabidopsis C2 plants were inoculated by infiltration with wild-type Pto DC3000, a $\Delta h r c$ non-pathogenic mutant strain, or a wild-type strain expressing the heterologous effector AvrRpt2, which triggers an additional level of defences, the hypersensitive response (HR) [43]. Consistently with the transcriptional repression of the defence response, C2 plants are more susceptible to wild-type Pto DC3000 than wild-type plants when bacteria are infiltrated into the leaves (bypassing bacterial entry into the plant tissues) (Figure 4A), although no significant differences were found after infiltration with non-pathogenic or avirulent bacteria (Figure 4B).

A

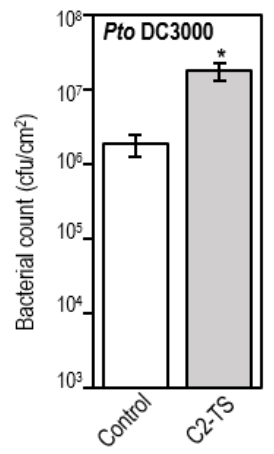

B

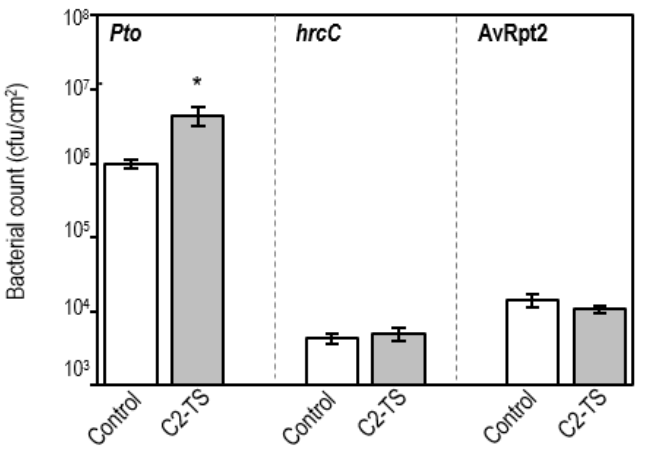

Figure 4. Cont. 

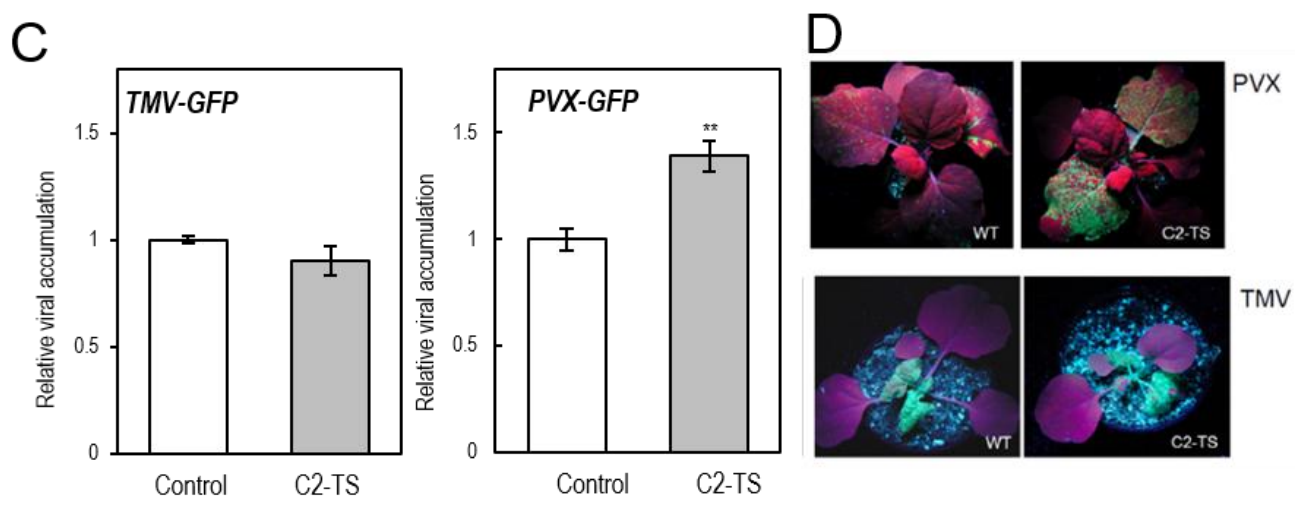

Figure 4. Transgenic C2-TS plants are more susceptible to Pseudomonas syringae pv. tomato DC3000 and Potato virus X. (A) Bacterial growth of Pto DC3000 in wild-type or C2-expressing Arabidopsis plants upon inoculation by infiltration. Samples were taken at $4 \mathrm{dpi}$. Values are the mean of five plants. Bars represent standard error. The asterisk indicates a statistically significant difference from the control sample $\left({ }^{*} p\right.$-value $\left.<0.05\right)$ according to a Student's $t$-test. Three independent experiments were performed with similar results; results from one representative experiments are shown; (B) Bacterial growth of wild-type Pto DC3000, a $\Delta h r c C$ mutant, or a wild-type strain expressing the heterologous effector AvrRpt2 on wild-type or C2-TS-expressing Arabidopsis plants. Values represent the average of five plants. Bars represent standard error. The asterisk indicates a statistically significant difference from the control sample $\left({ }^{*} p\right.$-value $\left.<0.05\right)$ according to a Student's $t$-test. Three independent experiments were performed with similar results; results from one representative experiments are shown; (C) Infection of wild-type (WT) or C2-TS-expressing N. benthamiana plants with PVX-GFP or TMV-GFP at $10 \mathrm{dpi}$. Values represent relative expression of viral RNA estimated by semi-quantitative RT-PCR, and are the average of ten infected plants. Bars represent standard error. Asterisks indicate a statistically significant difference from the control sample $\left({ }^{* *} p\right.$-value $\left.<0.01\right)$ according to a Student's $t$-test. Two independent experiments were performed with similar results; results from one representative experiment are shown; (D) Pictures of representative TMV-GFP and PVX-GFP infected plants under UV light.

To test the susceptibility to RNA viruses we agroinfiltrated Nicotiana benthamiana plants expressing C2 from TYLCSV (C2-TS plants), which also show reduced responses to exogenous MeJA [4], with infectious clones of Potato virus X (PVX) and Tobacco mosaic virus (TMV) labelled with GFP. C2-TS $N$. benthamiana plants were more susceptible to infection with PVX: the levels of GFP and the viral RNA expression in C2-TS plants were higher than in control plants when measured by semi-quantitative PCR (Figure 4C,D). However, no significant changes in viral accumulation were detected in plants inoculated with TMV-GFP (Figure 4). Altogether, these results suggest that C2 might be suppressing JA-induced basal defence responses.

\section{Discussion}

The C2 protein from geminiviruses, including the begomoviruses TYLCSV and TYLCV, has been shown to hinder the function of the SCF E3 ubiquitin ligases in the plant cell, possibly through its interaction with CSN5, catalytic subunit of the SCF regulator CSN [4]. Whereas this effect of C2 has been observed for several SCF complexes regulating diverse hormonal responses, the most pronounced transcriptional change resulting from transgenic expression of $\mathrm{C} 2$ in Arabidopsis is a suppression of the jasmonate response [4]. Since jasmonate signalling initiates with perception of the hormone by the $\mathrm{SCF}{ }^{\mathrm{CO} 11}$ complex, it is feasible to speculate that partial inhibition of this $\mathrm{E} 3$ by $\mathrm{C} 2$ could underlie the detected suppression of this response. In agreement with this, Arabidopsis plants expressing C2 are not only less sensitive to jasmonates, but also to the bacterial JA-Ile mimic coronatine, also perceived by the $\mathrm{SCF}^{\mathrm{CO} 1}$ complex (Figures $\mathrm{A} 1$ and 1 ). However, why the effect of $\mathrm{C} 2$ is more noticeable on the 
$\mathrm{SCF}^{\mathrm{CO} 11}$ than on other SCF complexes, and what the molecular mechanisms underlying this specificity are, is unclear.

In addition, it is remarkable that C2 from TYLCSV does not generally affect JA-induced transcription, and on the contrary seems to suppress specific responses, namely JA-induced defences and secondary metabolism (Tables 1-3; Figure 3). Again, the lack of a general effect on JA responses supports the idea of additional mechanisms acting superimposed to the effect on the jasmonate receptor, possibly relying on additional protein-protein interactions with downstream signalling components. Promoter analysis of the subsets of JA-responsive genes affected by $\mathrm{C} 2$, contained in Tables 1 and 3 indicates a common over-representation of MYC- and MYC2-binding sites (data not shown), which suggests that $\mathrm{C} 2$ could be directly or indirectly interfering with the function of this family of transcription factors.

As expected from the transcriptional suppression of defence responses, C2-expressing Arabidopsis plants are more susceptible to the plant pathogenic bacterial strain Pto DC3000 when inoculated by infiltration (bypassing entry via stomata). This enhanced susceptibility, however, argues against an impairment of the apoplastic effect of coronatine. However, we cannot rule out the possibility that C2 may have additional targets impacting the interaction between the plant and P. syringae. Interestingly, since no differences can be detected in inoculations with the non-pathogenic mutant $\Delta h r c \mathrm{C}$ or the strain expressing the HR-inducing effector AvrRpt2, C2 seems to be suppressing basal defence responses specifically. Additionally, N. benthamiana plants expressing C2 are more susceptible to the RNA virus PVX. JA-induced terpenoids have been recently shown to play a role in anti-viral defence against PVX [28] and, therefore, the C2-mediated suppression of JA could underlie the enhanced viral performance. No differences could be observed, however, in infections with the RNA virus TMV; these results are in agreement with the previous finding that jasmonate signalling does not affect susceptibility to this virus [44], although, strikingly, it seems to be required for systemic resistance [32].

Although the observation that C2 suppresses the jasmonate response has been well documented, a series of questions remain open. For example, the potential additional molecular mechanism conferring specificity in the suppression of this response is still elusive. Importantly, it also remains to be determined whether the observed effect in Arabidopsis also occurs in tomato, which is the virus' natural host; and, assuming this is the case, what the biological effect on both the virus itself and its insect vector is. Future work will be required to gain further understanding of this function of the viral $\mathrm{C} 2$ protein, and to get a comprehensive picture of its relevance for plant-virus-insect interactions.

\section{Experimental Section}

\subsection{Plant Material and Growth Conditions}

Wild-type Arabidopsis thaliana used in this study is the Columbia ecotype. Seeds were surface-sterilized and sown on MS agar plates with $30 \mathrm{~g} / \mathrm{L}$ sucrose. Plates were cold-treated for 2 to 6 days at $4{ }^{\circ} \mathrm{C}$. Seedlings were grown at $20{ }^{\circ} \mathrm{C}$ under fluorescent white light (fluence rate of $40-60 \mu \mathrm{mol} \cdot \mathrm{m}^{-2} \cdot \mathrm{s}^{-1}$ ) with a $16 \mathrm{~h}$ light $/ 8 \mathrm{~h}$ dark photoperiod. For root growth inhibition assays, MS plates were placed in a vertical orientation for five days, and seedlings were then transferred to MS plates containing the $50 \mu \mathrm{M}$ MeJA. Root length was scanned five days later using the ImageJ software (http://rsb.info.nih.gov/ij).

The transgenic Arabidopsis plants expressing C2 from TYLCSV and TYLCV and the transgenic Nicotiana benthamiana plants expressing TYLCSV C2 are described elsewhere [4].

For transcriptomic analysis, T2 seedlings of C2-TS transgenic Arabidopsis plants were grown on MS with kanamycin for seven days, and then treated with $50 \mu \mathrm{M}$ MeJA or mock solution for $10 \mathrm{~h}$. Three independent replicates were performed. For these analyses, T3 homozygous LUC2 (PRB1::LUC) transgenic plants [45] resistant to kanamycin were used as control. Previously, the hormonal response of LUC2 had been proven to be identical to that of the wild-type in the aforementioned assays.

$N$. benthamiana plants were grown in soil at $22{ }^{\circ} \mathrm{C}$ in long day conditions $(16 \mathrm{~h}$ light $/ 8 \mathrm{~h}$ dark photoperiod). 


\subsection{Bacterial Infections}

Pseudomonas syringae pv. tomato DC3000 (Cuppels, 1986), a mutant strain unable to produce coronatine (CFA ${ }^{-} \mathrm{CMA}^{-}$; [46]), a $\Delta h r c \mathrm{C}$ mutant [47], or a bacterial strain expressing the heterologous effector AvrRpt2 [48] were grown at $28^{\circ} \mathrm{C}$ in LB medium supplemented with rifampicin $(15 \mu \mathrm{g} / \mathrm{mL})$ and kanamycin $(15 \mu \mathrm{g} / \mathrm{mL}$; in the case of Pto AvrRpt2). Bacteria were suspended in $10 \mathrm{mM} \mathrm{MgCl}$ before inoculations. Four to five-week old Arabidopsis plants were either inoculated by infiltrating with a $5 \times 10^{4} \mathrm{cfu} / \mathrm{mL}$ bacterial suspension using a blunt syringe, or inoculated by dipping for $30 \mathrm{~s}$ in a $5 \times 10^{7} \mathrm{cfu} / \mathrm{mL}$ bacterial suspension containing 0.02\% silwet L-77 (Crompton Europe LTD, Evesham, UK). Symptoms were evaluated at $4 \mathrm{dpi}$. Samples were taken from inoculated leaves at $4 \mathrm{dpi}$ using a $10 \mathrm{~mm}$-diameter cork borer. Three disks were taken per plant, placed into $1 \mathrm{~mL}$ of $10 \mathrm{mM} \mathrm{MgCl}$, and homogenized by mechanical disruption. Serial dilutions of the resulting bacterial suspensions were plated onto LB plates supplemented with of cycloheximide $(2 \mu \mathrm{g} / \mathrm{mL})$ and rifampicin $(15 \mu \mathrm{g} / \mathrm{mL})$.

\subsection{RNA Extraction, cRNA Preparation, and Affymetrix GeneChip ${ }^{\circledR}$ Hybridization}

The generation of these data has been described previously [49]. In brief, seven-day-old LUC2 and transgenic C2-TS Arabidopsis seedlings were treated with a $50 \mathrm{M}$ MeJA o mock solution for $10 \mathrm{~h}$. Three biological and three technical replicates were used. Total RNA was isolated from three replicates of MeJA- or mock-treated wild-type and transgenic C2-TS seedlings using TRIzol (Invitrogen, Carlsbad, CA, USA) and subsequently cleaned using RNeasy MinElute Cleanup Kit (Qiagen, Hilden, Germany). RNA quantity and quality were assessed with a Nanodrop ND-1000 spectrophotometer (Labtech, Ringmer, East Sussex, UK) and an Agilent 2100 bioanalyzer (Agilent Technologies, Santa Clara, CA, USA), respectively.

Microarray hybridization was carried out at the Unité de Recherche en Génomique Végétale (Evry, France), using Affymetrix GeneChip ${ }^{\circledR}$ ATH1.

All raw and normalized transcriptomic data are available through the CATdb database (project AFFY_MeJA_Arabidopsis) and from the Gene Expression Omnibus (GEO) repository at the National Center for Biotechnology Information (NCBI), under accession number GSE18667.

\subsection{Viral Infections}

Tobacco mosaic virus (TMV)-GFP and Potato virus X (PVX)-GFP are described elsewhere [50]. Infections in wild-type and transgenic C2-TS N. benthamiana were performed by agroinoculation as described in [50]. GFP expression was monitored at seven and 10 days post-inoculation (dpi), and samples were taken at $10 \mathrm{dpi}$.

\subsection{Quantitative Real-Time PCR ( $q P C R$ )}

Primer pairs for real-time PCR were designed using Primer 3 software (http:/ / frodo.wi.mit. $\mathrm{edu} /$ primer3/). Gene-specific primers were chosen so that the PCR products were 100-300 bp. Total RNA was extracted from seedlings using RNAeasy Plant Mini Kit (Qiagen, Hilden, Germany) and treated on column with Dnase (Qiagen). $1 \mu \mathrm{g}$ total RNA was used for first-strand cDNA synthesis using oligo(dT) primers and SuperScript II reverse transcriptase reagent (Invitrogen) following the manufacturer's instructions. For real-time PCR, the reaction mixture consisted of cDNA first-strand template, primer mix ( $5 \mu \mathrm{mol}$ each) and SsoFast ${ }^{\mathrm{TM}}$ EvaGreen ${ }^{\circledR}$ (BIO-RAD, Hercules, CA, USA) in a total volume of $25 \mu \mathrm{L}$. The PCR conditions were: $10 \mathrm{~min}$ at $95^{\circ} \mathrm{C}$, and 40 cycles of $30 \mathrm{~s}$ at $95^{\circ} \mathrm{C}$ and $30 \mathrm{~s}$ at $60^{\circ} \mathrm{C}$. The reactions were performed using a Rotor-Gene real-time cycler (Qiagen). A relative quantification real-time PCR method was used to compare expression of the genes in transgenic versus non-transgenic line [51]. Relative quantification describes the change in expression of the target gene in a test sample relative to calibrator sample. Actin was used as the internal control. The sample of LUC2 transgenic plants was used as the calibrator, with the expression level of the sample set to one. 
Each data point is the mean value from three experimental replicate determinations. Three biological replicates were used.

For quantification of PXV-GFP and TMV-GFP, total RNA was extracted from the third leave of each infected N. benthamiana plant using RNAeasy Plant Mini Kit (Qiagen) and treated on column with Dnase (Qiagen). cDNA synthesis was performed as previously described. Virus GFP accumulation was assessed by semi-quantitative PCR using primers for GFP (Up-mGFP: AGTGGAGAGGGTG AAGGTGA; low-mGFP: AAAGGGCAGATTGTGTGGAC) and the following conditions: $94{ }^{\circ} \mathrm{C}, 30 \mathrm{~s}$; $55{ }^{\circ} \mathrm{C}, 30 \mathrm{~s} ; 72{ }^{\circ} \mathrm{C}, 40 \mathrm{~s}$ (22 cycles). Primers to amplify the 16S-23S rDNA interspacer (ITS) were used as control (ITS 25S fw: ATAACCGCATCAGGTCTCCA; ITS 25S Rv: CCGAAGTTACGGATCCATTT) using the same PCR conditions, 16 cycles. Bands were quantified using ImageJ software (http://rsb.info.nih.gov/ij).

Acknowledgments: The authors are grateful to members of their groups and to Miguel Ángel Botella for fruitful discussions. Work in the Bejarano lab is funded by a Project Grant from the Ministerio de Economía y Competitividad (MINECO, Spain; AGL2013-48913-C2-2-R); work in the Beuzón lab is funded by a Project Grant from the Ministerio de Economía y Competitividad (MINECO, Spain; BIO2012-35641); work in the Lozano-Durán lab is funded by the Shanghai Center for Plant Stress Biology, Chinese Academy of Sciences.

Author Contributions: E.R.B. conceived the project. T.R.-D., A.P.M. and R.L.-D. designed and performed experiments. C.R.B., R.L.-D. and E.R.B. supervised the work. R.L.-D. wrote the manuscript, which all authors read, edited and approved.

Conflicts of Interest: The authors declare no conflict of interest.

\section{Appendix}

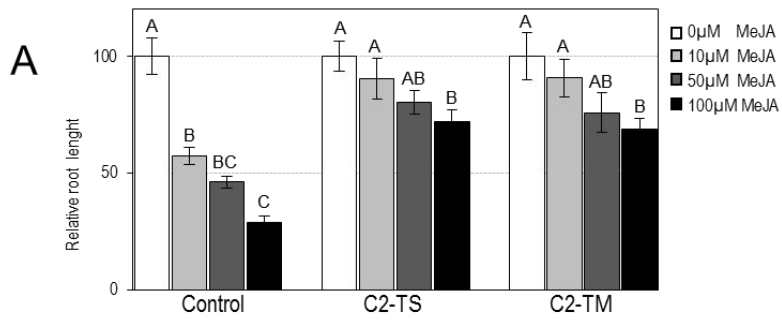

B

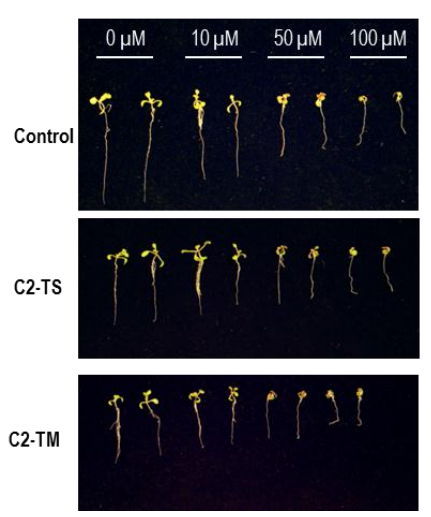

Figure A1. Root growth inhibition assays in C2-expressing plants. (A) Relative root length of wild-type Col-0 (Control), C2-TS (plants expressing the C2 gene from TYLCSV), and C2-TM (plants expressing the C2 gene from TYLCV) Arabidopsis seedlings in increasing concentrations of MeJA (0, 10, 50, and $100 \mu \mathrm{M})$. The values are the mean of at least ten seedlings. Bars represent standard error. One-way ANOVA Tukey's Multiple comparison tests were used to distinguish differences among samples at $p$-value $<0.05$. Different letters indicate statistically significant difference. Experiments were repeated three times with similar results; results from one representative experiment are shown; (B) Pictures of representative seedlings used in (A). 
A
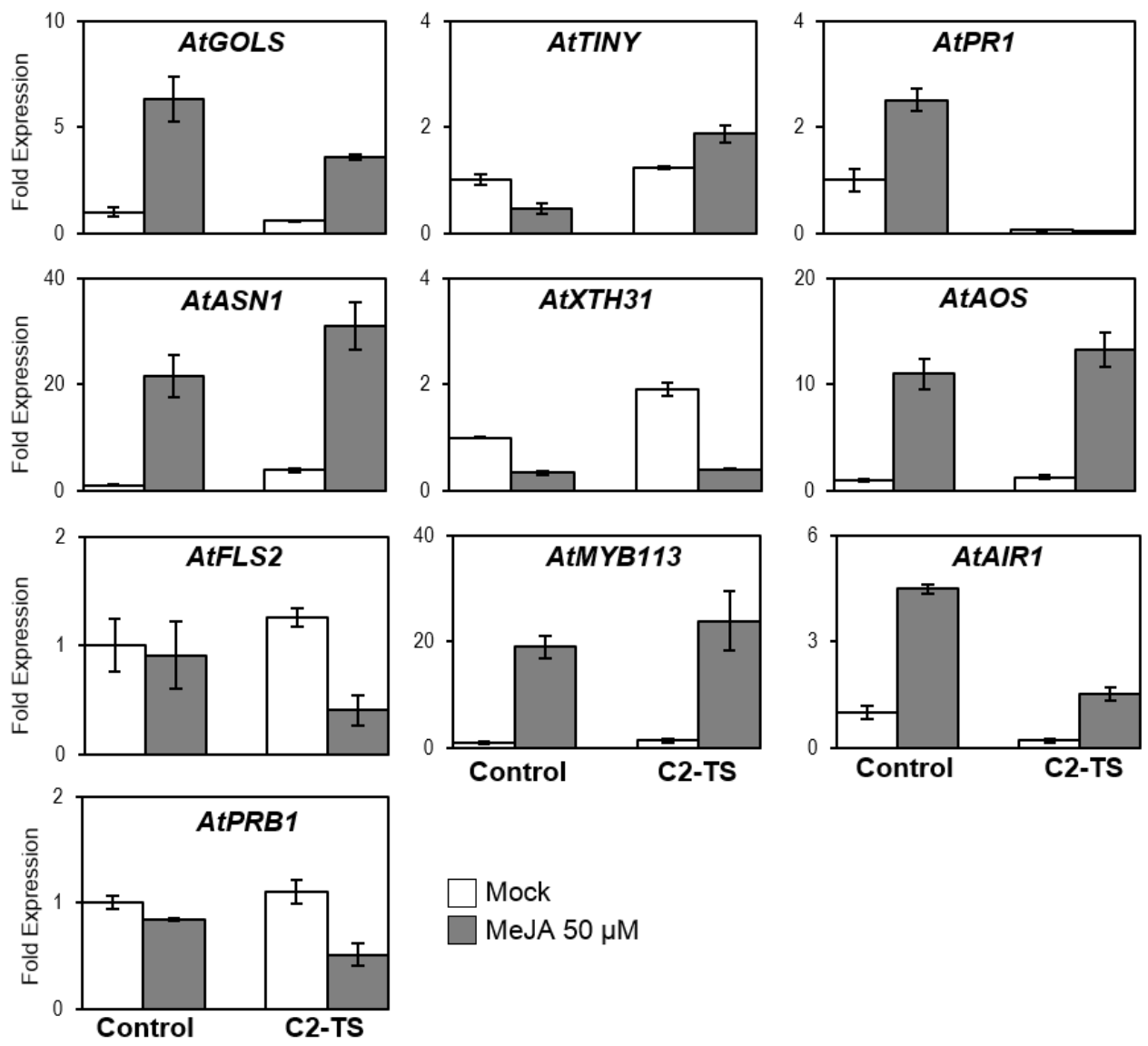

Mock

MeJA $50 \mu \mathrm{M}$

$\mathrm{B}$

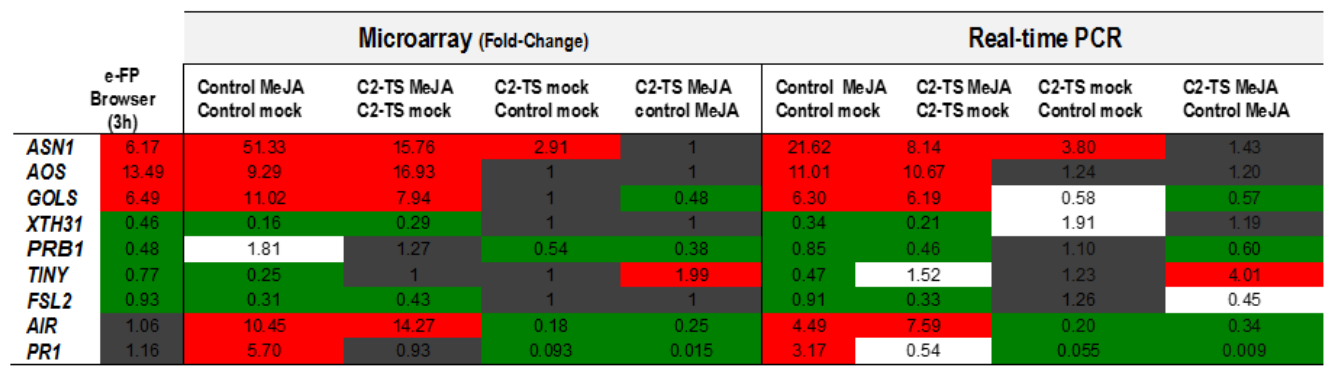

Figure A2. Expression levels of JA-regulated and control genes in Arabidopsis transgenic C2-TS and control plants for microarray validation. (A) Relative expression level of AtASN1 (At3g47340), AtAOS1 (At5g42650), AtGOLS (At2g47180), AtXTH31 (At3g44990), AtPRB1 (At2g14580), AtTINY (At5g25810), AtFLS2; (At5g46330), AtAIR1 (At4g12550) and AtPR1 (At2g14610) genes in transgenic C2-TS and control Arabidopsis seedlings, mock- or MeJA-treated, determined by real-time PCR. Values are the mean of three technical replicates. Bars represent standard error; (B) Comparison between microarray and real-time PCR expression data of the MeJA-regulated and control genes in Arabidopsis transgenic C2-TS and control plants used in (A). Up- and down-regulation are shown in red and green, respectively; lack of differential expression or coincidence between the two methods are shown in grey and white, respectively. Values from eFP browser after $3 \mathrm{~h}$ of JA treatment are also represented [52] (Arabidopsis eFP Browser. Available online: http://bar.utoronto.ca/efp/cgi-bin/efpWeb.cgi). The numbers represent the expression value in fold change. 


\section{References}

1. Hanley-Bowdoin, L.; Bejarano, E.R.; Robertson, D.; Mansoor, S. Geminiviruses: Masters at redirecting and reprogramming plant processes. Nat. Rev. Microbiol. 2013, 11, 777-788. [CrossRef] [PubMed]

2. Chandran, S.A.; Jeyabharathy, C.; Usha, R. The C2 protein of Bhendi yellow vein mosaic virus plays an important role in symptom determination and virus replication. Virus Genes 2014, 48, 203-207. [CrossRef] [PubMed]

3. Etessami, P.; Callis, R.; Ellwood, S.; Stanley, J. Delimitation of essential genes of cassava latent virus DNA 2. Nucleic Acids Res. 1988, 16, 4811-4829. [CrossRef] [PubMed]

4. Lozano-Duran, R.; Rosas-Diaz, T.; Gusmaroli, G.; Luna, A.P.; Taconnat, L.; Deng, X.W.; Bejarano, E.R. Geminiviruses subvert ubiquitination by altering CSN-mediated derubylation of SCF E3 ligase complexes and inhibit jasmonate signaling in Arabidopsis thaliana. Plant Cell 2011, 23, 1014-1032. [CrossRef] [PubMed]

5. Sung, Y.K.; Coutts, R.H. Mutational analysis of potato yellow mosaic geminivirus. J. Gen. Virol. 1995, 76 , Pt 7. 1773-1780. [CrossRef] [PubMed]

6. Wartig, L.; Kheyr-Pour, A.; Noris, E.; De Kouchkovsky, F.; Jouanneau, F.; Gronenborn, B.; Jupin, I. Genetic analysis of the monopartite tomato yellow leaf curl geminivirus: Roles of V1, V2, and C2 ORFs in viral pathogenesis. Virology 1997, 228, 132-140. [CrossRef] [PubMed]

7. Sunter, G.; Bisaro, D.M. Transactivation in a geminivirus: AL2 gene product is needed for coat protein expression. Virology 1991, 180, 416-419. [CrossRef]

8. Sunter, G.; Bisaro, D.M. Transactivation of geminivirus AR1 and BR1 gene expression by the viral AL2 gene product occurs at the level of transcription. Plant Cell 1992, 4, 1321-1331. [CrossRef] [PubMed]

9. Buchmann, R.C.; Asad, S.; Wolf, J.N.; Mohannath, G.; Bisaro, D.M. Geminivirus AL2 and L2 proteins suppress transcriptional gene silencing and cause genome-wide reductions in cytosine methylation. J. Virol. 2009, 83, 5005-5013. [CrossRef] [PubMed]

10. Chandran, S.A.; Levy, Y.; Mett, A.; Belausov, E.; Ramakrishnan, U.; Gafni, Y. Mapping of functional region conferring nuclear localization and karyopherin alpha-binding activity of the $\mathrm{C} 2$ protein of bhendi yellow vein mosaic virus. J. Gen. Virol. 2012, 93, Pt 6. 1367-1374. [CrossRef] [PubMed]

11. Dong, X.; van Wezel, R.; Stanley, J.; Hong, Y. Functional characterization of the nuclear localization signal for a suppressor of posttranscriptional gene silencing. J. Virol. 2003, 77, 7026-7033. [CrossRef] [PubMed]

12. Jackel, J.N.; Buchmann, R.C.; Singhal, U.; Bisaro, D.M. Analysis of geminivirus AL2 and L2 proteins reveals a novel AL2 silencing suppressor activity. J. Virol. 2015, 89, 3176-3187. [CrossRef] [PubMed]

13. Luna, A.P.; Morilla, G.; Voinnet, O.; Bejarano, E.R. Functional analysis of gene-silencing suppressors from tomato yellow leaf curl disease viruses. Mol. Plant-Microbe Interact. 2012, 25, 1294-1306. [CrossRef] [PubMed]

14. Wang, H.; Buckley, K.J.; Yang, X.; Buchmann, R.C.; Bisaro, D.M. Adenosine kinase inhibition and suppression of RNA silencing by geminivirus AL2 and L2 proteins. J. Virol. 2005, 79, 7410-7418. [CrossRef] [PubMed]

15. Wang, H.; Hao, L.; Shung, C.Y.; Sunter, G.; Bisaro, D.M. Adenosine kinase is inactivated by geminivirus AL2 and L2 proteins. Plant Cell 2003, 15, 3020-3032. [CrossRef] [PubMed]

16. Gimenez-Ibanez, S.; Boter, M.; Solano, R. Novel players fine-tune plant trade-offs. Essays Biochem. 2015, 58, 83-100. [CrossRef] [PubMed]

17. Chini, A.; Fonseca, S.; Fernandez, G.; Adie, B.; Chico, J.M.; Lorenzo, O.; Garcia-Casado, G.; Lopez-Vidriero, I.; Lozano, F.M.; Ponce, M.R.; et al. The JAZ family of repressors is the missing link in jasmonate signalling. Nature 2007, 448, 666-671. [CrossRef] [PubMed]

18. Thines, B.; Katsir, L.; Melotto, M.; Niu, Y.; Mandaokar, A.; Liu, G.; Nomura, K.; He, S.Y.; Howe, G.A.; Browse, J. JAZ repressor proteins are targets of the $\mathrm{SCF}(\mathrm{COI} 1)$ complex during jasmonate signalling. Nature 2007, 448, 661-665. [CrossRef] [PubMed]

19. Boter, M.; Ruiz-Rivero, O.; Abdeen, A.; Prat, S. Conserved MYC transcription factors play a key role in jasmonate signaling both in tomato and Arabidopsis. Genes Dev. 2004, 18, 1577-1591. [CrossRef] [PubMed]

20. Lorenzo, O.; Chico, J.M.; Sanchez-Serrano, J.J.; Solano, R. JASMONATE-INSENSITIVE1 encodes a MYC transcription factor essential to discriminate between different jasmonate-regulated defense responses in Arabidopsis. Plant Cell 2004, 16, 1938-1950. [CrossRef] [PubMed] 
21. Fernandez-Calvo, P.; Chini, A.; Fernandez-Barbero, G.; Chico, J.M.; Gimenez-Ibanez, S.; Geerinck, J.; Eeckhout, D.; Schweizer, F.; Godoy, M.; Franco-Zorrilla, J.M.; et al. The Arabidopsis bHLH transcription factors MYC3 and MYC4 are targets of JAZ repressors and act additively with MYC2 in the activation of jasmonate responses. Plant Cell 2011, 23, 701-715. [CrossRef] [PubMed]

22. Pauwels, L.; Barbero, G.F.; Geerinck, J.; Tilleman, S.; Grunewald, W.; Perez, A.C.; Chico, J.M.; Bossche, R.V.; Sewell, J.; Gil, E.; et al. NINJA connects the co-repressor TOPLESS to jasmonate signalling. Nature 2010, 464, 788-791. [CrossRef] [PubMed]

23. Pauwels, L.; Goossens, A. The JAZ proteins: A crucial interface in the jasmonate signaling cascade. Plant Cell 2011, 23, 3089-3100. [CrossRef] [PubMed]

24. Chung, H.S.; Koo, A.J.; Gao, X.; Jayanty, S.; Thines, B.; Jones, A.D.; Howe, G.A. Regulation and function of Arabidopsis JASMONATE ZIM-domain genes in response to wounding and herbivory. Plant Physiol. 2008, 146, 952-964. [CrossRef] [PubMed]

25. Agudelo-Romero, P.; Carbonell, P.; de la Iglesia, F.; Carrera, J.; Rodrigo, G.; Jaramillo, A.; Perez-Amador, M.A.; Elena, S.F. Changes in the gene expression profile of Arabidopsis thaliana after infection with Tobacco etch virus. Virol. J. 2008, 5, 92. [CrossRef] [PubMed]

26. Kovak, M.; Müller, A.; Milanovic Jarh, D.; Milavec, M.; Düchting, P.; Ravnikar, M. Multiple hormone analysis indicates involvement of jasmonate signalling in the early defence of potato to potato virus YNTN. Biol. Plant. 2009, 53, 195-199. [CrossRef]

27. Lewsey, M.G.; Gonzalez, I.; Kalinina, N.O.; Palukaitis, P.; Canto, T.; Carr, J.P. Symptom induction and RNA silencing suppression by the cucumber mosaic virus 2b protein. Plant Signal. Behav. 2010, 5, 705-708. [CrossRef] [PubMed]

28. Li, R.; Tee, C.S.; Jiang, Y.L.; Jiang, X.Y.; Venkatesh, P.N.; Sarojam, R.; Ye, J. A terpenoid phytoalexin plays a role in basal defense of Nicotiana benthamiana against Potato virus X. Sci. Rep. 2015, 5, 9682. [CrossRef] [PubMed]

29. Ryu, C.M.; Murphy, J.F.; Mysore, K.S.; Kloepper, J.W. Plant growth-promoting rhizobacteria systemically protect Arabidopsis thaliana against Cucumber mosaic virus by a salicylic acid and NPR1-independent and jasmonic acid-dependent signaling pathway. Plant J. 2004, 39, 381-392. [CrossRef] [PubMed]

30. Vigliocco, A.; Bonamico, B.; Alemano, S.; Miersch, O.; Abdala, G. Stimulation of jasmonic acid production in Zea mays $\mathrm{L}$. infected by the maize rough dwarf virus-Rio Cuarto. Reversion of symptoms by salicylic acid. Biocell 2002, 26, 369-374. [PubMed]

31. Yang, J.Y.; Iwasaki, M.; Machida, C.; Machida, Y.; Zhou, X.; Chua, N.H. betaC1, the pathogenicity factor of TYLCCNV, interacts with AS1 to alter leaf development and suppress selective jasmonic acid responses. Genes Dev. 2008, 22, 2564-2577. [CrossRef] [PubMed]

32. Zhu, F.; Xi, D.H.; Yuan, S.; Xu, F.; Zhang, D.W.; Lin, H.H. Salicylic acid and jasmonic acid are essential for systemic resistance against tobacco mosaic virus in Nicotiana benthamiana. Mol. Plant-Microbe Interact. 2014, 27, 567-577. [CrossRef] [PubMed]

33. Westwood, J.H.; Lewsey, M.G.; Murphy, A.M.; Tungadi, T.; Bates, A.; Gilligan, C.A.; Carr, J.P. Interference with jasmonic acid-regulated gene expression is a general property of viral suppressors of RNA silencing but only partly explains virus-induced changes in plant-aphid interactions. J. Gen. Virol. 2014, 95, 733-739. [CrossRef] [PubMed]

34. Salvaudon, L.; de Moraes, C.M.; Yang, J.Y.; Chua, N.H.; Mescher, M.C. Effects of the virus satellite gene betaC1 on host plant defense signaling and volatile emission. Plant Signal. Behav. 2013, 8, e23317. [CrossRef] [PubMed]

35. Ascencio-Ibanez, J.T.; Sozzani, R.; Lee, T.J.; Chu, T.M.; Wolfinger, R.D.; Cella, R.; Hanley-Bowdoin, L. Global analysis of Arabidopsis gene expression uncovers a complex array of changes impacting pathogen response and cell cycle during geminivirus infection. Plant Physiol. 2008, 148, 436-454. [CrossRef] [PubMed]

36. Gongora-Castillo, E.; Ibarra-Laclette, E.; Trejo-Saavedra, D.L.; Rivera-Bustamante, R.F. Transcriptome analysis of symptomatic and recovered leaves of geminivirus-infected pepper (Capsicum annuum). Virol. J. 2012, 9, 295. [CrossRef] [PubMed]

37. Geng, X.; Jin, L.; Shimada, M.; Kim, M.G.; Mackey, D. The phytotoxin coronatine is a multifunctional component of the virulence armament of Pseudomonas syringae. Planta 2014, 240, 1149-1165. [CrossRef] [PubMed] 
38. Melotto, M.; Underwood, W.; Koczan, J.; Nomura, K.; He, S.Y. Plant stomata function in innate immunity against bacterial invasion. Cell 2006, 126, 969-980. [CrossRef] [PubMed]

39. Uppalapati, S.R.; Ishiga, Y.; Wangdi, T.; Kunkel, B.N.; Anand, A.; Mysore, K.S.; Bender, C.L. The phytotoxin coronatine contributes to pathogen fitness and is required for suppression of salicylic acid accumulation in tomato inoculated with Pseudomonas syringae pv. tomato DC3000. Mol. Plant-Microbe Interact. 2007, 20, 955-965. [CrossRef] [PubMed]

40. Jung, C.; Lyou, S.H.; Yeu, S.; Kim, M.A.; Rhee, S.; Kim, M.; Lee, J.S.; Choi, Y.D.; Cheong, J.J. Microarray-based screening of jasmonate-responsive genes in Arabidopsis thaliana. Plant Cell Rep. 2007, 26, 1053-1063. [CrossRef] [PubMed]

41. Nemhauser, J.L.; Hong, F.; Chory, J. Different plant hormones regulate similar processes through largely nonoverlapping transcriptional responses. Cell 2006, 126, 467-475. [CrossRef] [PubMed]

42. Katari, M.S.; Nowicki, S.D.; Aceituno, F.F.; Nero, D.; Kelfer, J.; Thompson, L.P.; Cabello, J.M.; Davidson, R.S.; Goldberg, A.P.; Shasha, D.E.; et al. VirtualPlant: A software platform to support systems biology research. Plant Physiol. 2010, 152, 500-515. [CrossRef] [PubMed]

43. Kunkel, B.N.; Bent, A.F.; Dahlbeck, D.; Innes, R.W.; Staskawicz, B.J. RPS2, an Arabidopsis disease resistance locus specifying recognition of Pseudomonas syringae strains expressing the avirulence gene avrRpt2. Plant Cell 1993, 5, 865-875. [CrossRef] [PubMed]

44. Oka, K.; Kobayashi, M.; Mitsuhara, I.; Seo, S. Jasmonic acid negatively regulates resistance to Tobacco mosaic virus in tobacco. Plant Cell Physiol. 2013, 54, 1999-2010. [CrossRef] [PubMed]

45. Santamaria, M.; Thomson, C.J.; Read, N.D.; Loake, G.J. The promoter of a basic PR1-like gene, AtPRB1, from Arabidopsis establishes an organ-specific expression pattern and responsiveness to ethylene and methyl jasmonate. Plant Mol. Biol. 2001, 47, 641-652. [CrossRef] [PubMed]

46. Brooks, D.M.; Hernandez-Guzman, G.; Kloek, A.P.; Alarcon-Chaidez, F.; Sreedharan, A.; Rangaswamy, V.; Penaloza-Vazquez, A.; Bender, C.L.; Kunkel, B.N. Identification and characterization of a well-defined series of coronatine biosynthetic mutants of Pseudomonas syringae pv. tomato DC3000. Mol. Plant-Microbe Interact. 2004, 17, 162-174. [CrossRef] [PubMed]

47. Mudgett, M.B.; Staskawicz, B.J. Characterization of the Pseudomonas syringae pv. tomato AvrRpt2 protein: Demonstration of secretion and processing during bacterial pathogenesis. Mol. Microbiol. 1999, 32, 927-941. [PubMed]

48. Macho, A.P.; Ruiz-Albert, J.; Tornero, P.; Beuzon, C.R. Identification of new type III effectors and analysis of the plant response by competitive index. Mol. Plant Pathol. 2009, 10, 69-80. [CrossRef] [PubMed]

49. Lozano-Durán, R.; García, I.; Huguet, S.; Balzergue, S.; Romero, L.C.; Bejarano, E.R. Geminivirus C2 protein represses genes involved in sulphur assimilation and this effect can be counteracted by jasmonate treatment. Eur. J. Plant Pathol. 2012, 134, 49-59. [CrossRef]

50. Peart, J.R.; Cook, G.; Feys, B.J.; Parker, J.E.; Baulcombe, D.C. An EDS1 orthologue is required for N-mediated resistance against tobacco mosaic virus. Plant J. 2002, 29, 569-579. [CrossRef] [PubMed]

51. Panchuk, I.I.; Volkov, R.A.; Schoffl, F. Heat stress- and heat shock transcription factor-dependent expression and activity of ascorbate peroxidase in Arabidopsis. Plant Physiol. 2002, 129, 838-853. [CrossRef] [PubMed]

52. Winter, D.; Vinegar, B.; Nahal, H.; Ammar, R.; Wilson, G.V.; Provart, N.J. An "electronic fluorescent pictograph" browser for exploring and analyzing large-scale biological data sets. PLoS ONE 2007, 2, e718. [CrossRef] [PubMed]

(C) 2016 by the authors; licensee MDPI, Basel, Switzerland. This article is an open access article distributed under the terms and conditions of the Creative Commons by Attribution (CC-BY) license (http:/ / creativecommons.org/licenses/by/4.0/). 